Avalaible online: https://ejournal.iai-tribakti.ac.id/index.php/pgmi

Article doi: https://doi.org/10.33367/jiee.v3i2.1930

Submission: 2021-08-25 Review: 2021-09-28 Accepted: 2021-09-29

\title{
Kualitas Soal Pilihan Ganda Kelas VI Tema 1 MI MHM Banjarsari Ngronggot Nganjuk
}

\section{Quality Multiple Choice Questions Semester Class VI Theme 1 MHM Islamic Elementary School Banjarsari Ngronggot Nganjuk}

\author{
Liana Mutholiin', Bustanul Arifin² \\ 12 Institut Agama Islam Tribakti \\ 1 femihakim@gmail.com;2arifinbustan65@gmail.com
}

\begin{abstract}
This research was conducted to find out how to compile and analyze the Odd End Semester Assessment questions at MI MHM Banjarsari, and to determine the quality of the multiple choice items of the Odd End Semester Assessment Grade VI Theme 1 MI MHM Banjarsari Academic Year 2019/2020. The research design used in the analysis of the quality of the multiple choice items Final Assessment of the odd semester class VI Theme 1 MI MHM Banjarsari Academic Year 2019/2020 is quantitative descriptive. Data collection in this study used document analysis method. The source of the data of this study was the question sheets and answer sheets of students participating in the Odd End Semester Assessment (PAS) of Class VI Theme 1 MI MHM Banjarsari. Calculation of the level of difficulty, different power, the effectiveness of deceit, the validity and reliability of the instrument in this study using the Anates $\mathrm{V}$ 0.4 program. The results of the research that have been done show that the quality of the final semester semester 1 question items in MI MHM Banjarsari in 2019/2020 from a total of 35 multiple choice questions viewed from the difficulty level obtained as many as 10 items (28.57\%) with the difficulty level of questions in very easy category, 7 items (20\%) in the easy category, 14 items $(40 \%)$ in the medium category, 3 items $(8.57 \%)$ in the difficult category, and 1 item $(2.86 \%)$ in the very difficult category. Judging from the different power of the final semester assessment questions, theme 1 found 5 items (14.29\%) in the very bad category, 13 items (37.14\%) in the bad category, 6 items $(17.14 \%)$ in the category enough, 10 items (28.57\%) in the good category, and 1 item (2.86\%) in the very good category. Judging from the deception of answers to the odd semester final assessment questions, there were 3 questions $(8.57 \%$ in the very bad category, 6 questions $(17.14 \%)$ in the bad category, 4 questions (11.48\%) in the good category, and 22 questions $(62.86 \%)$ in the very good category Judging from the validity of the odd semester final evaluation questions theme 1 obtained valid questions (significant / very significant) of 15 questions (42.86\%) and for invalid questions a total of 20 questions (57.14\%) In terms of reliability, it was obtained 0.81 . Thus it can be concluded that the quality of the items can be said to be less good.
\end{abstract}

Keyword: Item analysis, Anates Version 4.0. 


\begin{abstract}
Abstrak
Penelitian ini dilakukan untuk mengetahui cara menyusun dan menganalisis soal Penilaian Akhir Semester ganjil di MI MHM Banjarsari, dan untuk mengetahui kualitas butir soal pilihan ganda Penilaan Akhir Semester ganjil kelas VI Tema 1 MI MHM Banjarsari Tahun Ajaran 2019/2020. Desain penelitian yang digunakan dalam analisis kualitas butir soal pilihan ganda Penilaan Akhir Semester ganjil kelas VI Tema 1 MI MHM Banjarsari Tahun Ajaran 2019/2020 adalah deskriptif kuantitatif. Pengumpulan data dalam penelitian ini menggunakan metodeanalisis dokumen. Sumber data penelitian ini adalah lembar soal dan lembarjawaban siswa peserta Penilaian Akhir Semester (PAS) ganjil Kelas VI Tema 1 MI MHM Banjarsari. Penghitungan tingkat kesulitan, daya beda, efektivitas pengecoh, validitas dan reliabilitas instrumen pada penelitian ini menggunakan program Anates V 0.4. Hasil penelitian yang telah dilakukan menunjukan bahwa kualitas butir soal penilaian akhir semester ganjil tema 1 di MI MHM Banjarsari tahun 2019/2020 dari total 35 soal pilihan ganda ditinjau dari tingkat kesukaran didapatkan sebanyak 10 butir soal (28,57\%) dengan tingkat kesukaran soal dalam kategori sangat mudah, 7 butir soal (20\%) dalam kategori mudah, 14 butir soal (40\%) dalam kategori sedang, 3 butir soal $(8,57 \%)$ dalam kategori sukar, dan 1 butir soal (2,86\%) dalam kategori sangat sukar. Ditinjau dari daya beda soal penilaian akhir semester ganjil tema 1 didapatkan 5 butir soal $(14,29 \%)$ dalam kategori sangat jelek, 13 butir soal $(37,14 \%)$ dalam kategori jelek, 6 butir soal $(17,14 \%)$ dalam kategori cukup, 10 butir soal $(28,57 \%)$ dalam kategori baik, dan 1 butir soal $(2,86 \%)$ dalam kategori sangat baik. Ditinjau dari pengecoh jawaban soal penilaian akhir semester ganjil tema 1 terdapat sebanyak 3 soal $(8,57 \%$ dalam kategori sangat buruk, 6 soal $(17,14 \%)$ dalam kategori buruk, 4 soal (11,48\%) dalam kategori baik, dan 22 soal $(62,86 \%)$ dalam kategori sangat baik. Ditinjau dari validitas soal penilaian akhir semester ganjil tema 1 didapatkan soal valid (signifikan/sangat signifikan) sejumlah 15 soal $(42,86 \%)$ dan untuk soal yang tidak valid sejumlah 20 soal $(57,14 \%)$. Ditinjau dari reabilitas didapatkan sebesar 0.81 . Dengan demikian dapat disimpulkan bahwa kualitas butir soal bisa dikatakan kurang baik.
\end{abstract}

Kata Kunci: Analisis butir soal, Anates Versi 4.0.

\section{Pendahuluan}

Analisis kualitas penilaian ini dilakukan untuk mengetahui kualitas penilaian baik kualitas penilaian secara keseluruhan maupun kualitas butir soalnya. ${ }^{1}$ Dengan adanya analisis penilaian maka akan nampak bahwa penilaian yang digunakan memiliki kualitas yang baik, cukup baik, atau tidak baik. Penilaian yang digunakan

1Z. Arifin, Evaluasi Pembelajaran, (Bandung: PT Remaja Rosdakarya,2013), h. 246. 
oleh guru hendaknya memiliki kualitas yang baik dilihat dari berbagai segi diantaranya yaitu dari segi Validitas, Reliabilitas, Tingkat Kesukaran, Daya Pembeda,dan Efektivitas Pengecoh. $^{2}$

Penilaian menruapkan rangkaian kegiatan evaluasi. Sudijono menyatakan bahwa evaluasi adalah sebuah tindakan atau proses untuk menentukan nilai dari sesuatu yang dapat dikatakan sebagai suatu proses yang berlangsung dalam rangka menentukan nilai dari segala sesuatu yang berhubungan dengan pendidikan, sehingga dapat ditentukan mutu suatu pendidikan. ${ }^{3}$ Berdasarkan kutipan tersebut, dapat disimpulkan bahwa evaluasi merupakan suatu komponen dalam proses pendidikan yang digunakan untuk menilai kemampuan peserta didik selama masa pembelajaran berlangsung,

2 Alpusari, M. Analisis Butir Soal Konsep Dasar IPA 1 melalui Penggunaan Program Komputer Anates Versi 4.0 For Windows. Jurnal Primary, tersedia Online di https://media.neliti.com/media/ publications/258202-analisis-butir-soalkonsep-dasar-ipa-1m2d710558 .pd (diakses pada 27 Januari 2021).

3 Amanaturrakhmah, I., Kardoyo., \& Rifai, A. (2017). Manajemen Pembelajaran el Bidayah: Journal of Islamic Elementary Education Volume 3, Nomor 2, September 2021 sehingga mutu pendidikan dapat ditentukan melalui kegiatan evaluasi.

Evaluasi dapat dikatakan sebagai suatu alat untuk mengukur tingkat keberhasilan pembelajaran. Bentuk-bentuk evaluasi yang dilaksanakan dalam satuan pendidikan berupa bentuk evaluasi tes atau non tes. Evaluasi tes dapat berupa penilaian harian, penugasan, Penilaian Tengah Semester (PTS), Penilaian Akhir Semester (PAS), Ujian Nasional (UN), dan Ujian Akhir Sekolah Berstandar Nasional (UASBN), sedangkan evaluasi non tes dapat berupa praktikpraktik yang dilakukan dalam kegiatan pembelajaran seperti praktik menyanyi, menari, dan lain-lain. 4 Evaluasi yang berbasis tes dilakukan untuk mengukur kemampuan peserta didik sebagai wujud dari keberhasilan pembelajaran, sedangkan evaluasi yang berbasis non tes bertujuan mengongkretkan pengetahuan peserta

Tematik di Kelas Tinggi SD Percontohan Kabupaten Indramayu. Journal of Primary Education, tersedia Online di https://journal.unnes.ac.id/sju/index.php/j pe/article/view/17570 (diakses pada 27 Januari 2021)

4 Kusaeri,Acuan \& Hasil Penilaian Proses \& Hasil Belajar dalam Kurikulum 2013. (Yogyakarta: Ar-ruzz Media.2014), h. 134 
didik, agar kemampuan keterampilannya dapat berkembang dengan baik.

MI MHM Banjarsari dalam melaksanakan evaluasi hasil belajar, mengadakan penilaian akhir Semester ganjil untuk menilai pembelajaran yang telah dilaksanakan. Berdasarkan wawancara yang telah dilakukan, diketahui bahwa guru belum melakukan analisis kualitas butir soal terhadap soal yang akan diujikan. Hal ini dikarenakan kesibukan guru dengan berbagai persyaratan administratif yang menjadi tuntutan sehingga analisis terhadap kualitas butir soal kurang diperhatikan. ${ }^{5}$

Hasil studi pendahuluan dengan wawancara salah satu guru kelas IV di Gugus Wahidin Sudirohusodo, diperoleh informasi bahwa pembuatan soal-soal evaluasi PTS atau PAS hanya dilakukan oleh tim penyusun soal yang terdiri dari beberapa guru yang dibagi penugasannya dalam satu tema. Sistematika pembagiannya adalah satu guru dalam satu tim ditunjuk menyusun soal dalam satu tema. Penyusunan soal tersebut tidak diuji kevalidan soal dan menurut penuturan Pak Mulyani, sering ditemui ada beberapa soal yang keluar dari tema. Sebelumnya, penelitian tentang analisis butir soal pernah dilakukan oleh beberapa peneliti, namun hal ini masih menarik untuk diteliti.

Sejatinya, untuk mengetahui kualitas penilaian, perlu dilakukan dengan menganalisis soal secara keseluruhan maupun butir soal yang menjadi bagian dari penilaian di dalamnya yang meliputi analisis terhadap Validitas, Reliabilitas, Tingkat Kesukaran, Daya Pembeda, dan Efektivitas Pengecoh. Dari hasil analisis tersebut dapat diidentifikasi soalsoal yang baik, cukup baik, dan soal yang tidak baik. Soal yang baik bisa dimasukkan ke dalam bank soal, soal yang cukup baik direvisi terlebih dahulu sebelum dimasukkan ke dalam bank soal, dan soal yang tidak baik sebaiknya di buang. Hal ini dapat

Kota Medan. Universitas Negeri Medan. Jurnal Pelita Pendidikan, tersedia online di http:// jurnalpelitapendidikan. pdf (diakses pada 1 Februari 2021)

el Bidayah: Journal of Islamic Elementary Education Volume 3, Nomor 2, September 2021 
menjadi petunjuk bagi pembuat soal dalam mengadakan perbaikan.

Dengan adanya permasalahan tersebut, maka peneliti bermaksud untuk melakukanpenelitian mengenai kualitas soal penilaian akhir semester dengan judul "Analisis Kualitas Butir Soal Pilihan Ganda Penilaian Akhir Semester Ganjil Kelas VI Tema 1 MI MHM Banjarsari Kecamatan Ngronggot Tahun Ajaran 2019/2020".

\section{Metode}

Desain penelitian yang digunakan dalam analisis kualitas butir soal pilihan ganda Penilaan Akhir Semester ganjil kelas VI Tema 1 MI MHM Banjarsari Tahun Ajaran 2019/2020 adalah deskriptif kuantitatif. Pengumpulan data dalam penelitian ini menggunakan metode analisis dokumen. ${ }^{6}$ Sumber data penelitian ini adalah lembar soal dan lembarjawaban siswa peserta Penilaian Akhir Semester (PAS) ganjil Kelas VI Tema 1 MI MHM Banjarsari.

6 Lubis, Syarifuddin, \& Dongoran (2016). Analisis Butir Soal dan Kemampuan Siswa Menjawab Tes UN dan UAS Ganjil Mata Pelajaran Biologi Kelas XI SMAN/MAN di Kota Medan. Universitas Negeri Medan. Jurnal Pelita Pendidikan, tersedia online di http:// jurnalpelitapendidikan. pdf (diakses pada 1 Februari 2021)
Penghitungan tingkat kesulitan, daya beda, efektivitas pengecoh, validitas dan reliabilitas instrumen pada penelitian ini menggunakan program Anates V 0.4. ${ }^{7}$

\section{Temuan dan Pembahasan Temuan penelitian}

Berhasil tidaknya pembelajaran dapat ditentukan dari hasil evaluasi. Evaluasi dilakukan dengan tujuan menentukan ketercapaian tujuan pembelajaran yang telah ditetapkan. Evaluasi dapat dilakukan melalui tes yang digunakan untuk mengevaluasi kegiatan dalam ranah kognitif. Tes yang berkualitas dapat mengukur kemampuan siswa dan tes tersebut mampu mengetahui sejauh mana kemampuan peserta didik.

Penilaian Akhir Semester (PAS) gasal tema 1 tahun ajaran 2019/2020 MI MHM Banjarsari disusun oleh tim penyusun soal yang tergabung dalam Kelompok Kerja Guru (KKG) yang ditunjuk oleh setiap gugus yang ada di Kabupaten Tegal yang kemudian diajukan oleh UPTD. Guru yang terpilih

\footnotetext{
${ }^{7}$ Ahmad Khoirul Mustamir, Resistensi Kepemimpinan Perempuan Eks - Hizbut Tahrir Indonesia Dalam Lembaga Pendidikan Dasar Islam Di Kota Kediri, h. 27. https://jurnal.iainponorogo.ac.id/index.php Lijougs/article/view/2492 diakses 5 Mei 2021
} 
Oleh: Liana Mutholiin dan Bustanul Arifin

dan disetujui oleh UPTD, akan ditugaskan membuat soal. Umumnya, satu tema disusun oleh satu guru penyusun soal. Soal PAS menggunakan unit dan penyusun soal tidak menganalisis butir soal secara kualitatif terlebih dahulu, sehingga belum diketahui kualitas butir soalnya. Dengan demikian, perlu dilakukan penelitian mengenai analisis butir soal guna menentukan kualitas butir soal PAS gasal tersebut.

Adapun Analisis Butir Soal adalah kajian mengenai pertanyaanpertanyaan tes untuk memperoleh pertanyaan yang memiliki kualitas memadai. Analisis butir soal dilakukan dengan tujuan untuk memperbaiki kualitas soal karena pada kenyataannya dalam dunia pendidikan masih terdapat soal-soal tes yang memiliki kekurangan atau bahkan kesalahan. ${ }^{8}$ Kualitas yang dimiliki pada soal tes harus seimbang, maksudnya adalah soal-soal tersebut memiliki spesifikasi soal mudah, sedang, dan sukar secara proposional. ${ }^{9}$

8 Rohmah. (2017). Analisis Butir Soal Evaluasi Semester Ganjil Kelas IV IImu Pengetahuan Sosial Se-Kecamatan Mojoroto Kota Kediri Tahun Ajaran 2016/2017. Universitas Nusantara PGRI Kediri. Jurnal Online, tersedia di https://simki.unpkediri.ac.id (diakses pada 3 Februari 2021)

9 Lubis, Syarifuddin, \& Dongoran (2016). Analisis Butir Soal dan Kemampuan Siswa Menjawab Tes UN dan UAS Ganjil Mata 200
Analisis butir soal memiliki banyak manfaat, antara lain: membantu pengguna tes mengevalusi tes yang digunakan, mendukung penulisan soal agar efektif, dapat memperbaiki tes di kelas, dan meningkatkan validitas dan reliabilitas soal. Pelaksanaan analisis butir soal dapat dilakukan secara kualitatif dan kuantitaif. Berikut penjelasan secara lebih rinci:

1. Analisis Butir Soal secara Kualitatif Analisis butir soal secara kualitatif dapat dilaksanakan berdasarkan kaidah penulisan soal. Aspek-aspek yang harus diperhatikan dalam analisis kualitatif yaitu penelaahan soal dari segi materi, kontruksi, bahasa/budaya, dan kunci jawaban/pedoman penskorannya. Departemen Pendidikan Nasional, menjelaskan bahwa terdapat dua teknik yang dapat digunakan dalam analisis butir soal secara kualitatif yaitu teknik moderator dan teknik panel. ${ }^{10}$

Pelajaran Biologi Kelas XI SMAN/MAN di Kota Medan. Universitas Negeri Medan. Jurnal Pelita Pendidikan, tersedia online di http:// jurnalpelitapendidikan. pdf (diakses pada 1 Februari 2021

10 Departemen Pendidikan Nasional. 2008. Panduan Analisis Butir Soal. Tersedia Online di http:// gurupembaharu.com/ home/ download- / panduan-analisis-butirsoal.pdf (diakses 1 Februari 2021)

el Bidayah: Journal of Islamic Elementary Education Volume 3, Nomor 2, September 2021 
Oleh: Liana Mutholiin dan Bustanul Arifin

Teknik moderator merupakan teknik berdiskusi yang dalam pelaksanaannya melibatkan satu orang sebagai penengah. Analisis soal menggunakan teknik ini berarti butir soal didiskusikan secara bersama-sama dengan melibatkan beberapa ahli seperti guru yang memberikan materi, ahli materi, pengembang kurikulum, ahli penilaian, ahli bahasa, serta ahli yang berlatar belakang psikologi. Sedangkan dalam teknik panel, analisis butir soal dilakukan berdasarkan kaidah penulisan butir soal yang meliputi segi materi, konstruksi, bahasa/budaya, kebenaran kunci jawaban/pedoman penskoran yang dalam pelaksanaannya melibatkan beberapa penelaah. ${ }^{11}$

2. Analisis Butir Soal secara Kuantitatif

Departemen Pendidikan Nasional menjelaskan bahwa, analisis butir soal secara kuantitatif merupakan penelaahan butir soal yang berdasarkan data empirik dari soal yang diujikan. Terdapat dua pendekatan dalam analisis butir soal secara kuantitatif, yaitu

11 Rohmah. (2017). Analisis Butir Soal Evaluasi Semester Ganjil Kelas IV Ilmu Pengetahuan Sosial Se-Kecamatan Mojoroto Kota Kediri Tahun Ajaran 2016/2017. Universitas Nusantara PGRI Kediri. Jurnal Online, tersedia di https:// simki.unpkediri.ac.id (diakses pada 3 Februari 2021) pendekatan klasik dan modern. ${ }^{12}$ Analisis butir soal secara klasik merupakan penelaahan soal melalui informasi yang diperolah dari jawaban peserta didik guna meningkatkan mutu soal menggunakan teori klasik. Teknik ini, terdapat beberapa kelebihan yaitu murah, mudah, dapat dilaksanakan secara cepat, sederhana, dan dapat menggunkan data yang diperoleh dari beberapa peserta didik. Aspek yang harus diperhatikan dalam analisis butir soal menggunakan pendekatan klasik adalah sebagai berikut:

(1) Validitas

Arikunto menyatakan bahwa, validitas dalam sebuat tes dapat ditentukan melalui hasil pemikiran dan pengalaman. ${ }^{13}$ Menurut Sudijono, butir soal dapat dikatakan valid, apabila skor soal tersebut memiliki hubungan positif yang signifikan dengan skor totalnya. Variabel terikat diduduki oleh skor total, sedangkan variabel bebas diduduki oleh skor butir soal.

Sudijono menjelaskan bahwa, setiap butir soal dengan jawaban betul

12 Departemen Pendidikan Nasional. 2008. Panduan Analisis Butir Soal. Tersedia Online di http:// gurupembaharu.com/ home/ download- /panduan-analisis-butirsoal.pdf (diakses 1 Februari 2021)

13 Azwar, S.. Reliabilitas dan Validitas Edisi 4. (Yogyakarta: Pustaka Pelajar, 2016), h.78 
mendapat skor satu (1) dan setiap jawaban salah mendapat skor nol (0). Data tersebut dalam kajian statistik disebut data diskret murni atau data dikotomik. Skor total adalah hasil penjumlahan dari setiap skor butir soal yang merupakan data kontinu. Menurut teori, apabila data diskret atau dikotomik merupakan variabel I dan data kontinu merupakan variabel II, maka untuk mencari korelasi antara variabel I dan II dapat dengan teknik korelasi point biserial. Angka indeks korelasi berlambangkan RPBI.

(2) Reliabilitas

Reliabilitas maknanya adalah ketepatan hasil yang diperoleh dari suatu pengukuran. Suatu tes dapat dikatakan reliabel, jika hasil pengukurannya tetap ketika diteskan berkalikali. Menurut Arikunto, suatu tes dapat dikatakan mempunyai tingkat reliabilitas tinggi ketika tes tersebut dapat memberikan hasil yang tetap. ${ }^{14}$

Sudjana mendefinisikan, reliabilitas alat penilaian merupakan ketetapan alat tersebut dalam menilai apa

14 Rohmah. (2017). Analisis Butir Soal Evaluasi Semester Ganjil Kelas IV Ilmu Pengetahuan Sosial Se-Kecamatan Mojoroto Kota Kediri Tahun Ajaran 2016/2017. Universitas Nusantara PGRI Kediri. Jurnal Online, tersedia di https://simki.unpkediri.ac.id (diakses pada 3 Februari 2021) 202 yang dinilainya. Kapanpun alat penilaian tersebut digunakan akan memberikan hasil yang sama. Tujuan utama menghitung reliabilitas skor pada tes adalah untuk menentukan tingkat ketepatan dan keajegan skor tes. Depdiknas menyatakan bahwa, indeks reliabilitas berkisar antara 0-1 dengan ketentuan semakin tinggi koefisien reliabilitas (mendekati 1), semakin tinggi pula keajegan/ ketetapannya. ${ }^{15}$

\section{(3) Tingkat Kesukaran}

Tingkat kesukaran butir soal merupakan penentu mutu butir soal. Soal yang tidak terlalu mudah atau terlalu sukar dapat dikategorikan sebagai soal yang baik. Soal yang diberikan kepada peserta didik jika terlalu mudah, tidak akan mempertinggi usaha peserta didik dalam memecahkan masalah yang ada pada butir soal. Apabila soal terlalu sukar, maka akan menjadikan peserta didik memiliki keputusasaan dan tidak ada semangat untuk mencoba mengerjakannya kembali. Bilangan yang menunjukkan sukar atau mudahnya suatu soal disebut

15 Lubis, Syarifuddin, \& Dongoran (2016). Analisis Butir Soal dan Kemampuan Siswa Menjawab Tes UN dan UAS Ganjil Mata Pelajaran Biologi Kelas XI SMAN/MAN di Kota Medan. Universitas Negeri Medan. Jurnal Pelita Pendidikan, tersedia online di http:// jurnalpelitapendidikan. pdf (diakses pada 1 Februari 2021

el Bidayah: Journal of Islamic Elementary Education Volume 3, Nomor 2, September 2021 
Oleh: Liana Mutholiin dan Bustanul Arifin

indeks kesukaran yang besarnya antara 0,00 sampai 1,00. Indeks kesukaran yang besarnya 0,00 menunjukkan bahwa soal tersebut terlalu sukar, sebaliknya jika indeks 1,00 menunjukkan soal tersebut merupakan soal yang terlalu mudah (Arikunto, 2018:222). Sudjana menyatakan bahwa perbandingan antara soal mudahsedang-sukar dibuat dengan perbandingan 3-4-3 yang artinya, soal kategori mudah 30\%, soal kategori sedang 40\%, dan soal kategori sukar $30 \% .^{16}$

Berdasarkan penjelasan tersebut, dapat disimpulkan bahwa soal-soal yang terlalu mudah atau terlalu sukar bukan berarti tidak dapat digunakan, namun harus disesuaikan dengan mempertimbangkan situasi dan kondisi dengan ketentuan apabila mengendaki banyak peserta didik dinyatakan lulus, maka mengunakan butir soal yang berkategori mudah. Sebaliknya, jika menghendaki sedikit peserta didik yang lulus, maka butir soal disusun dengan kategori sangat sukar.

\begin{tabular}{ll}
${ }^{16}$ Amanaturrakhmah, & \multicolumn{1}{c}{ I., } \\
Kardoyo., \& $\quad$ Rifai, A. \\
(2017). Manajemen
\end{tabular} Tematik di Kelas Tinggi SD Percontohan Kabupaten Indramayu. Journal of Primary el Bidayah: Journal of Islamic Elementary Education Volume 3, Nomor 2, September 2021

\section{Pembahasan}

1. Tingkat Kesukaran

Tingkat kesukaran ialah peluang menjawab benar suatu soal pada tingkat kemampuan tertentu peserta didik. Soal yang baik memiliki tingkat kesukaran yang sedang yang artinya tidak terlalu mudah dan tidak terlalu sukar untuk dikerjakan. Adapun kriteria interpretasi hasil perhitungan tingkat kesukaran soal yaitu $\mathrm{P}=0,00$ termasuk kategori sangat sukar; 0,00< $\mathrm{P} \leq 0,30$ termasuk kategori sukar; 0,30 $<\mathrm{P} \leq 0,70$ termasuk kategori sedang; $0,70<\mathrm{P} \leq 1,00$ termasuk kategori mudah; dan $\mathrm{P}=1,00$ termasuk kategori soal sangat mudah.

Berdasarkan hasil pemeriksaan soal Soal Penilaian Akhir Semester Ganjil Tahun Ajaran 2019/2020 MI MHM Banjarsari menggunakan aplikasi Anates versi 4.0 terdapat 35 butir soal pilihan ganda terdapat sebanyak 10 butir soal (28,57\%) dengan tingkat kesukaran soal dalam kategori sangat mudah, 7 butir soal (20\%) dalam kategori mudah, 14 butir soal (40\%)

Education, tersedia Online di https://journal.unnes.ac.id/sju/index.php/j pe/article/view/17570 (diakses pada 27 Januari 2021) 
dalam kategori sedang, 3 butir soal $(8,57 \%)$ dalam kategori sukar, dan 1 butir soal $(2,86 \%)$ dalam kategori sangat sukar. Distribusi dari 35 soal tersebut berdasarkan tingkat kesukaran soal.

2. Daya Beda

Daya pembeda adalah kemampuan soal untuk membedakan peserta didik dengan kemampuan tinggi dan peserta didik dengan kemampuan rendah. Kategori interpretasi hasil perhitungan berdasarkan daya pembeda yaitu DP $\leq 0,00$ termasuk kategori sangat jelek; 0,00< DP $\leq 0,20$ termasuk kategori jelek; 0,20 < DP $\leq$ 0,40 termasuk kategori cukup; 0,40 < $\mathrm{DP} \leq 0,70$ termasuk kategori baik; dan $0,70<\mathrm{DP} \leq 1,00$ termasuk kategori sangat baik.

Berdasarkan hasil pemeriksaan soal Soal Penilaian Akhir Semester Ganjil Tahun Ajaran 2019/2020 MI MHM Banjarsari menggunakan aplikasi Anates versi 4.0 terdapat 35 butir soal pilihan ganda terdapat 5 butir soal $(14,29 \%)$ dalam kategori sangat jelek, 13 butir soal $(37,14 \%)$ dalam kategori jelek, 6 butir soal $(17,14 \%)$ dalam kategori cukup, 10 butir soal $(28,57 \%)$ dalam kategori baik, dan 1 butir soal (2,86\%) dalam kategori sangat baik. Distribusi dari 35 soal tersebut berdasarkan daya beda soal,

\section{Efektifitas Pengecoh}

Suatu pengecoh dapat dikatakan berfungsi apabila pengecoh paling tidak dipilih oleh5\% peserta tes atau lebih banyak dipilih oleh kelompok siswa yang belum paham materi.

Berdasarkan hasil pemeriksaan soal Penilaian Akhir Semester Ganjil Tahun Ajaran 2019/2020 MI MHM Banjarsari menggunakan aplikasi Anates versi 4.0 terdapat 35 butir soal pilihan ganda terdapat 140 pilihan jawaban (opsi) dengan keefektifan opsi (pengecoh) dalam kategori sangat baik sebanyak 20 opsi (14,29\%), kategori baik sebanyak 20 opsi (14,29\%), kategori kurang baik sebanyak 16 opsi (11,43\%), kategori buruk sebanyak 29 opsi $(20,71 \%)$, kategori sangat buruk sebanyak 10 opsi $(7,14 \%)$, sedangkan 45 opsi $(32,14 \%)$ merupakan kunci jawaban.

Pilihan ganda menunjukan hasil untuk jumlah butir soal yang 
valid (signifikan/sangat signifikan) sejumlah 15 soal $(42,86 \%)$ dan untuk soal yang tidak valid sejumlah 20 soal $(57,14 \%)$. Kemudian apabila 35 soal tersebut didistribusikan berdasarkan indeks validitasnya.

4. Reabilitas Soal

Berdasarkan hasil pemeriksaan soal Penilaian Akhir Semester Ganjil Tahun Ajaran 2019/2020 MI MHM Banjarsari menggunakan aplikasi Anates versi 4.0 terdapat 35 butir soal pilihan ganda menunjukan hasil bahwa reliabilitas tes sebesar 0.81 . Dengan hasil ini maka dapat dikatakan bahwa reliabilitas tes untuk pilihan ganda soal penilaian akhir semester ganjil tema 1 ini memiliki interpretasi yang sangat tinggi termasuk kedalam reliabilitas tes 0,80 - 1,00 ini berdasarkan rumus kriteria reliabilitas.

\section{Kesimpulan}

Berdasarkan hasil yang diperoleh dari analisis butir soal penilaian akhir semester ganjil tema 1 di MI MHM Banjarsari menggunakan aplikasi Anates versi 4.0 sebagai berikut, tingkat kesukaran soal penilaian akhir semester ganjil tema 1 sedang, hal ini berdasarkan dari hasil sebanyak 10 butir soal $(28,57 \%)$ dengan tingkat el Bidayah: Journal of Islamic Elementary Education Volume 3, Nomor 2, September 2021 kesukaran soal dalam kategori sangat mudah, 7 butir soal (20\%) dalam kategori mudah, 14 butir soal (40\%) dalam kategori sedang, 3 butir soal $(8,57 \%)$ dalam kategori sukar, dan 1 butir soal $(2,86 \%)$ dalam kategori sangat sukar. Daya beda soal penilaian akhir semester ganjil tema 1 cukup baik, hal ini dilihat dari hasil 5 butir soal $(14,29 \%)$ dalam kategori sangat jelek, 13 butir soal (37,14\%) dalam kategori jelek, 6 butir soal $(17,14 \%)$ dalam kategori cukup, 10 butir soal $(28,57 \%)$ dalam kategori baik, dan 1 butir soal (2,86\%) dalam kategori sangat baik. Pengecoh jawaban soal penilaian akhir semester ganjil tema 1 kategori tinggi. Hal ini dilihat dari hasil terdapat sebanyak 3 soal $(8,57 \%$ dalam kategori sangat buruk, 6 soal $(17,14 \%)$ dalam kategori buruk, 4 soal (11,48\%) dalam kategori baik, dan 22 soal $(62,86 \%)$ dalam kategori sangat baik.

\section{Daftar Pustaka}

Alpusari, M. Analisis Butir Soal Konsep Dasar IPA 1 melalui Penggunaan Program Komputer Anates Versi 4.0 For Windows. Jurnal Primary, tersedia Online di https://media.neliti.com/me dia/ publications/258202analisis-butir-soal-konsep- 
Oleh: Liana Mutholiin dan Bustanul Arifin

dasar-ipa-1m2d710558 .pd

(diakses pada 27 Januari 2021).

Amanaturrakhmah, I.,

Kardoyo., \&

Rifai, A. (2017).

Manajemen Pembelajaran

Tematik di Kelas Tinggi SD

Percontohan Kabupaten

Indramayu. Journal of

Primary Education,

tersedia Online di

https://journal.unnes.ac.id/sj

$\mathrm{u} /$ index.php/jpe/article/vie

w/17570 (diakses pada 27 Januari 2021)

Ahmad Khoirul Mustamir, Resistensi Kepemimpinan Perempuan Eks - Hizbut Tahrir Indonesia Dalam Lembaga Pendidikan Dasar Islam Di Kota Kediri, h. 27.

https://jurnal.iainponorogo.ac.id/i ndex.php/ijougs/article/view/2492 diakses 5 Mei 2021

Aksarahttps:/ /geografikritis.blogspot .com/2016/01/anates-v-409software-evaluasi.html Anidi, Evaluasi Program Pembelajaran. Yogyakarta:Parama

Publishing,2017

Arifin, Z. Evaluasi Pembelajaran.

Bandung: PT Remaja Rosdakarya, 2013

Arikunto, Suharsimi. Dasar-Dasar Evaluasi Pendidikan. Jakarta: PT. Bumi, 2011

Firmansyah, Hasim. Analisis Butir Soal Tes Plihan Ganda Mata Pelajaran Pendidikan Jasmani Olahraga dan Kesehatan Kelas VIII SMPN 1 Wonosari Tahun 2017/2018. Yogyakarta, 2018

Halik, Andi Surahma. Analisis Butir Soal Ujian Akhir Sekolah (UAS) Mata Pelajaran Matematika pada
Tahun 2016 SMP Negeri 36 Makassar. Makasar,2017

https:/ / suaidinmath.wordpress.com/ 2014/04/23/manfaatpenilaian-pembelajaran/. https:/ / bimbelbrilian.com/jen is-jenis-soal-untuk-evaluasipembelajaran-sekolah-besertacontohnya/

https://www.asikbelajar.com /pengertian-penilaian-hasilbelajar/

Isnaeni, Ahmad. Analisis Butir Soal Tes Plihan Ganda Mata Pelajaran Pendidikan JasmaniOlahraga dan Kesehatan Kelas VIII SMPN 1 Wonosari Tahun 2017/2018. Purworejo, 2018

Karim, Nurman. Kisi-kisi soal dan kartu soal, https:/ / nurmanspd. wordpress.com /2009/09/27/kisi- kisi-soaldan-kartu-soal/

Kurniawan, Tutut. Analisis Butir Soal Ujian Akhir Semester Gasal Mata Pelajaran IPS Sekolah Dasar, Journal of eElementary Education 4, no.1 , 2015

Lubis, Syarifuddin, \& Dongoran (2016). Analisis Butir Soal dan Kemampuan Siswa Menjawab Tes UN dan UAS Ganjil Mata Pelajaran Biologi Kelas XI SMAN/MAN di Kota Medan. Universitas Negeri Medan. Jurnal Pelita Pendidikan, tersedia online di http:// jurnalpelitapendidikan. pdf (diakses pada 1 Februari 2021

Paturusi, Aji. Analisis Butir Soal Ujian Akhir Semester Gasal (UAS) Mata Pelajaran Pendidikan Kewarganegaraan Kelas IV SDN 1 Banjarsari Kulon Kecamatan 
Kualitas Soal Pilihan Ganda Kelas VI Tema 1 MI MHMM Banjarsari Ngronggot Nganjuk Oleh: Liana Mutholiin dan Bustanul Arifin

Sumbang Tahun Ajaran

2016/2017. Purwokerto, 2018

Sukardi, Dewa Ketut dan Desak P. E.

Nila Kusmawati. Analisis Tes

Psikologis Tes Psikologis Teori

dan Praktik. Jakarta: Rineka

Cipta, 2009

Umronah, Analisis Kualitas Butir Soal

Ujian Akhir Semester Genap

Mata Pelajaran Ekonomi

Akuntansi Kelas XI PS SMA

Negeri 1 Imogiri Tahun Ajaran

2016/2017. Yogyakarta, 2018 